\title{
Allelic Variation and Haplotype Structure of the Dopamine Receptor Gene DRD2 in Naga Tribes of Manipur, India
}

\author{
Tabitha Panmei ${ }^{1 * *}$, Gangaina Kameih ${ }^{2}$, Siuli Mitra ${ }^{3}$, Gautam K. Kshatriya ${ }^{4}$ \\ ${ }^{1,2,3,4}$ Department of Anthropology, University of Delhi, Delhi 110007, India
}

\begin{abstract}
The present study investigates the extent of genetic affinities and to trace their evolutionary history among the three Naga tribal groups of Manipur. Three DRD2 markers were screened among 200 individuals belonging to different Naga tribal (Rongmei=60, Inpui $=78$, and Liangmai=62) groups using three sites (TaqI B, TaqID, and TaqIA) on the dopamine receptor D2 (DRD2) gene through allele and haplotype frequencies. All the three sites are found to be polymorphic. All the populations share six of the eight haplotypes pointing toward underlying genetic uniformity, which is reaffirmed by regression analysis of heterozygosity on genetic distance. The ancestral haplotype frequency $B 2 D 2 A 1$ is found to range between $6.8-19.2 \%$. Our finding reveals that the highest ancestral haplotype frequency among the Liangmai has been supported to the origin hypothesis that Liangmai (19.2\%) is the oldest among the three populations.
\end{abstract}

Keyword: DRD2 gene, Haplotype, Northeast, Subcontinent, and Tibeto-Burman.

\section{Introduction}

The Indian SUBCONTINENT is a reservoir of colossal cultural, ethnic, linguistic, and genetic diversity (Karve, 1961; Beteille, 1998; Majumder, 1998) with populations culturally stratified into endogamous tribal $(8.2 \%$ of the total population of India) (Census of India, 2001) and nontribal groups (Hindu caste populations and other religious groups) and classified under one of the four language families: Austro-Asiatic (AA), Dravidian (DR), Tibeto-Burman (TB), and Indo-European (IE). It harbors more genetic diversity than other comparable global regions (Majumder, 1998). The subcontinent has served as a major corridor for the dispersal of modern humans (Cann, 2001). It has witnessed multiple waves of migrations and gene flow from different parts of the world in prehistoric and historic times (Ratnagar, 1995; Thapar, 1995). Most of the immigrations have been through the north, northwest, western littoral, and north and northeastern parts of India. The northeast, as described by many, acted as a corridor for prehistoric human migrations and historic human invasions. A debate persists regarding whether northeast India was a corridor (Reddy et al. 2007) or a barrier (Cordaux et al., 2004) for human migrations. All the seven northeastern states including Manipur have international borders. Like other states, Manipur is also an ethnically and culturally diverse state. Its population is constituted by $60 \%-70 \%$ nontribal population groups, and the rest by 33 recognized tribal groups. As a whole, TibetoBurman speakers constitute less $2 \%$ of the India's total population (Malhotra and Vasulu, 1993). Northeast India is dominated by Tibeto-Burman speaking Mongoloid groups (Grierson, 1903, 1909) except the Khasi and its sub-tribes who are Mongoloid but speak dialects of Austro-Asiatic linguistic family.

The Dopamine D2 receptor (DRD2) is one of the five common human dopamine receptor genes that are expressed in the central nervous system and have been extensively studied in various world populations, including several Indian populations (Kidd et al., 1998; Vishwanathan et al.,
2003; Bhaskar et al., 2008; Prabhakaran et al., 2008; Saraswathy et al., 2009a, 2009b, 2009c; Kshatriya et al., 2010). It has for over a decade emerged as one of the several examples of genes being increasingly studied for both functional and evolutionary significance. This gene, spanning over $270 \mathrm{~kb}$ and mapped to locus 11q22.3-q23.1 (Grandy et al., 1989) encodes the D2 subtype of dopamine receptor. It is one of the five types of dopamine receptors encoded by five separate genes expressed in central nervous system. DRD2 is of special interest as it is a target site of many neuropsychiatric drugs, and is thus of prime concern in the fields of neurology, psychiatry, and endocrinology among others. Over the years haplotype analysis has emerged as a powerful tool for gaining insights into the population dynamics as it gives more meaningful insights both in evolutionary studies and disease-association studies than unlinked markers (Tisskoff et al., 1996; The international HapMap Consortium, 2005; Plagnol and Wall, 2006). With reference to the DRD2 locus, three single nucleotide polymorphisms are used to construct haplotypes important for analysis of evolutionary relationships in order of TaqI B (Hauge et al., 1991), TaqI D (Parsian et al., 1991), and TaqIA (Grandy et al., 1989). The TaqI B site is located 913bp upstream of the initiation codon in exon 2, the TaqI D site is located in intron 2, and the TaqI A site is located $10,542 \mathrm{bp}$ downstream of the termination codon. The ancestral alleles are B2, D2, and A1 (Castiglione et al., 1995; Kidd et al., 1996; Kidd et al., 1998), and B1, D1, and $\mathrm{A} 2$ are the corresponding derived alleles.

The Present studied populations i.e. Liangmai, Rongmei and Inpui are the indigenous Naga tribe living in the states of Assam, Manipur and Nagaland of northeast India. They are divided when the official boundaries were set by Government of India, making them a minority in each state. In Manipur, these tribal groups mostly concentrated in Tamenglong district of Manipur and some of these groups reside in Senapati District, and also in Imphal valley (capital city of Manipur). These tribal groups must have taken many centuries in moving down from the mountains of South- 


\section{International Journal of Science and Research (IJSR) \\ ISSN (Online): 2319-7064}

Index Copernicus Value (2013): 6.14 | Impact Factor (2014): 5.611

West China to the equally rugged Myanmar through its river valleys to the vast Islands of South-East Asia. Then they moved into the present habitat through different routes of migration (Grierson, 1903). They speak a language related to Bodo of Assam and that has been grouped under a subfamily of the Naga-Bodo within the Tibeto-Burman (Grierson, 1903). These tribes have their distinctive sociocultural, traditional and linguistic variants and genetic identity. Its tradition, culture and custom, remain intact but modern education, acceptance of Christianity and other modernizing forces appear to have disrupted it to some extent. These tribal groups declare that they are the descendents of the same ancestor on the basis of ethnocultural entity and they are uncertain about who among these tribal groups is the oldest one. During our fieldwork, we have come across many native elders from these groups claiming themselves as the oldest one. And so far few studies have been pointed out that Liangmai is the oldest among these studied groups (AZSU 2009; Pamei1949 (Edited by G. Gwangphun). Keeping this in view, the present study is aimed to investigate the extent of genetic affinities and to trace their evolutionary history among the three tribal groups of Manipur.

Table 1: Name of the presently studied population groups, linguistic group, ethnicity, sample sizes and area of sample collection

\begin{tabular}{|c|c|c|c|c|}
\hline Sl. No. & Population & $\begin{array}{c}\text { Linguisti } \\
\text { c group }\end{array}$ & Ethnic groups & $\begin{array}{c}\text { Area of sample } \\
\text { collection (sample } \\
\text { size) }\end{array}$ \\
\hline 1 & Rongmei & $\begin{array}{c}\text { Tibeto- } \\
\text { Burman }\end{array}$ & $\begin{array}{c}\text { Mongoloid, a } \\
\text { tribal group }\end{array}$ & $\begin{array}{c}\text { Imphal west and } \\
\text { Tamenglong District } \\
(60)\end{array}$ \\
\hline 2 & Inpui & $\begin{array}{c}\text { Tibeto- } \\
\text { Burman }\end{array}$ & $\begin{array}{c}\text { Mongoloid, a } \\
\text { tribal group }\end{array}$ & $\begin{array}{c}\text { Haochong area of } \\
\text { Tamenglong District } \\
\text { (78) }\end{array}$ \\
\hline 3 & Liangmai & $\begin{array}{c}\text { Tibeto- } \\
\text { Burman }\end{array}$ & $\begin{array}{c}\text { Mongoloid, a } \\
\text { tribal group }\end{array}$ & $\begin{array}{c}\text { Tamei of } \\
\text { Tamenglong District } \\
\text { and Senapati District } \\
\text { (62) }\end{array}$ \\
\hline
\end{tabular}

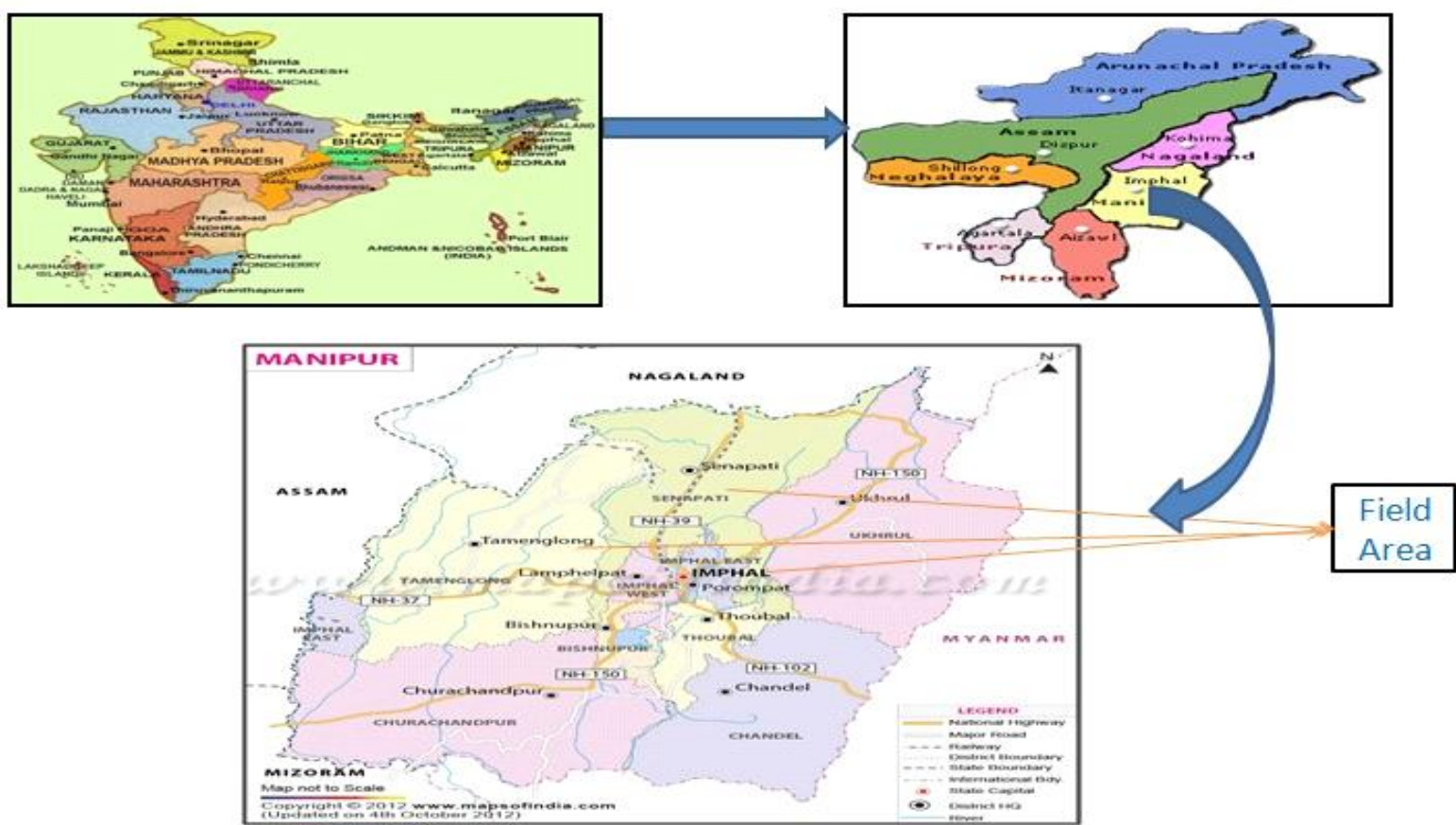

Figure 1: Map indicating the field area.

\section{Methods}

Three DRD2 markers were screened among 200 individuals belonging to different Naga tribal (Rongmei $=60$, Inpui $=78$, and Liangmai=62) groups of Manipur speaking TibetoBurman languages. The details of the study populations are given in Table 1. The geographical location of the studied area is shown in Figure $1.5 \mathrm{ml}$ of intravenous blood sample were collected from unrelated individuals by a trained medical practitioner after taking written consent from the subjects. The ethical clearance was obtained from Ethical Committee of the Department of Anthropology, University of Delhi.

\section{Laboratory analysis}

DNA was extracted from each blood sample using salting out method (Miller et al., 1988). Each DNA sample was screened for TaqI A, TaqI B and TaqI D sites of DRD2 gene through PCR-based amplifications using primers and protocols as described by Castiglione et al (1995) and Kidd et al. (1996). After PCR amplification it was digested with Taq1 sites as per the manufacturer's recommended conditions. The restricted fragments were separated in a $2 \%$ agarose gel at $100 \mathrm{~V}$. They were viewed in a gel documentation system.

\section{Statistical analysis}

Allele frequencies for each selected site were obtained using the software POPGENE version 1.31 (Yeh and Yang, 1999). Hardy-Weinberg equilibrium was calculated using the test for chi-square goodness of fit. Average heterozygosities 


\section{International Journal of Science and Research (IJSR) \\ ISSN (Online): 2319-7064 \\ Index Copernicus Value (2013): 6.14 | Impact Factor (2014): 5.611}

were calculated using the software DISPAN (Ota, 1993). The program ARLEQUIN version 3.1 (Excoffier et al. 2005) was used to calculate the maximum likelihood estimates of haplotype frequencies from the multisite marker typing data and the standardized pairwise linkage disequilibrium values (D') for each pair of marker. A regression analysis of heterozygosity on genetic distance (Harpending and Ward, 1982) was carried out to understand the population structure of the tribes under study.

\section{Results}

Table 2: Allele frequencies at Individual Sites of DRD2 Locus and Average Heterozygosity of Studied Population

\begin{tabular}{|c|c|c|c|c|c|c|c|}
\hline \multirow{2}{*}{ Population (Sample No.) } & \multicolumn{2}{|c|}{ TaqI B } & \multicolumn{2}{c|}{ TaqI D } & \multicolumn{2}{c|}{ TaqI A } & \multirow{2}{*}{$\begin{array}{c}\text { Average } \\
\text { Heterozygosity }\end{array}$} \\
\cline { 2 - 7 } & $\mathrm{B} 2$ & $\mathrm{~B} 1$ & $\mathrm{D} 2$ & $\mathrm{D} 1$ & $\mathrm{~A} 2$ & $\mathrm{~A} 1$ & $0.463 \pm 0.045$ \\
\hline Rongmei (60) & 0.7576 & 0.2424 & 0.5227 & 0.4773 & 0.5076 & 0.4924 & $0.480 \pm 0.009$ \\
\hline Inpui (78) & 0.6410 & 0.3590 & 0.5641 & 0.4359 & 0.6218 & 0.3782 & $0.479 \pm 0.010$ \\
\hline Liangmai (62) & 0.5968 & 0.4032 & 0.6532 & 0.3468 & 0.5968 & 0.4032 & \pm 0.032 \\
\hline
\end{tabular}

B2, D2, and A2 are positive alleles; B1, D1, and A1 are negative alleles.

Haplotype frequencies at DRD2 locus reveal that all populations have minimum seven haplotypes and share at least six haplotypes (B2D2A2, B2D2A1, B2D1A2, B1D2A1, B1D1A2 and B1D1A1) of the eight possible haplotypes (Table 3). Interestingly, Inpui is the only population that has all the eight possible haplotypes. Haplotypes B1D2A2 and B2D1A1 are absent among Rongmei and Liangmai respectively. The ancestral haplotype B2D2A1 ranged between 3.6\% in Rongmei and $6.4 \%$ in Liangmai. The two haplotypes having a combination of ancestral allele B2 and derived allele A2 (B2D2A2 and B2D1A2) together constitute the majority of haplotypes in all the study populations $(48.1 \%$ in Rongmei and 49.7 in Inpui) while in Liangmai population B2D2A1 is the $2^{\text {nd }}$ majority haplotype and comprises $49.5 \%$ of the haplotypes in this group along with B2D2A2.
The allele frequencies at DRD2 sites of the three Naga tribes of Manipur are given in Table 2. All the three sites are polymorphic among the three tribes. Of the three sites the greater variation was seen at the TaqI B site. B2 allele is found to be most frequent in Rongmei, while D2 is preponderant in Liangmai. However, ancestral allele A1 is found to be least frequent in all the three tribes and Rongmei showed the highest frequency of A1 allele. All the populations are found to be in Hardy Weinberg equilibrium for each site after applying chi-square test for goodness of fit. The average heterozygosity among the three tribes of Manipur ranged between 46.3\% (Rongmei) and 48\% (Inpui) and showed a low level of diversity.
Table 3: Haplotype frequency at three Dopamine Receptor D2 sites among the study population

\begin{tabular}{|c|c|c|c|}
\hline Haplotypes & Rongmei & Inpui & Liangmai \\
\hline B2D2A2 & 0.311 & 0.255 & 0.303 \\
B2D2A1 & $\mathbf{0 . 1 3 9}$ & $\mathbf{0 . 0 6 8}$ & $\mathbf{0 . 1 9 2}$ \\
\hline B2D1A2 & 0.170 & 0.242 & 0.103 \\
\hline B2D1A1 & 0.130 & 0.077 & 0.000 \\
\hline B1D2A2 & 0.000 & 0.084 & 0.144 \\
\hline B1D2A1 & 0.049 & 0.158 & 0.016 \\
\hline B1D1A2 & 0.036 & 0.047 & 0.064 \\
\hline B1D1A1 & 0.165 & 0.070 & 0.180 \\
\hline N & 60 & 78 & 62 \\
\hline
\end{tabular}

Data on pairwise linkage disequilibrium showed statistically significant among Rongmei and Inpui between Taq1A and Taq1B sites, Among Liangmai between Taq1B and Taq1D and Inpui between Taq1A and Taq1D (Table 4).

Table 4: Pairwise Linkage Disequillibrium values at DRD2 Locus

\begin{tabular}{|c|c|c|c|c|c|c|}
\hline Population & \multicolumn{2}{|c|}{ LD between Taq1 B and Taq1 D } & \multicolumn{2}{c|}{ LD between Taq1A and Taq1 B } & LD between Taq1 A and Taq1 D \\
\hline & LD & Chi-Square & LD & Chi-Square & LD & Chi-Square \\
\hline Rongmei & 0.002 & 9.712 & $0.322^{\mathrm{a}}$ & 0.979 & 0.023 & 5.150 \\
\hline Inpui & 0.001 & 11.287 & $0.662^{\mathrm{a}}$ & 0.192 & $0.185^{\mathrm{a}}$ & 1.758 \\
\hline Liangmai & $0.315^{\mathrm{a}}$ & 1.011 & 0.011 & 6.330 & 0.008 & 7.114 \\
\hline
\end{tabular}

a indicate significant levels to test whether the disequilibrium value differs from zero (one degree freedom). Values not in ${ }^{a}$ indicate that the test was not significant $(\mathrm{p}>0.05)$

$\mathrm{LD}=$ linkage disequilibrium

Harpending and Ward (1982) explained that local fluctuation in the frequencies of biochemical markers is caused by genetic drift and gene flow among groups counteracting the effect of genetic drift indicating that local structure is nearly exclusively driven by migration and drift. They showed that the genetic distance $\left(\mathrm{r}_{i i}\right)$ of the $i$ th subpopulation from a hypothetical centroid of all subpopulations is related to the average heteroygosity $\left(H_{i}\right)$ of the $i$ th subpopulation. If gene flow from outside is uniform, then $H_{\mathrm{i}}=b\left(1-r_{\mathrm{ii}}\right)$, with the absolute value of $\mathrm{b}$ being equal to
$H$, and the average heteroygosity in the pooled population and, therefore, regression of heterozygosity on genetic distances would show a linear relationship. Thus, regression of heteroygosity on genetic distance was performed in three tribes of Manipur (Table 5) and the analysis was consistent with linearity of this relationship.

Table 5: Average Heterozygosity $\left(H_{\mathrm{i}}\right)$ and Genetic Distances from the centroid $\left(r_{\mathrm{ii}}\right)$ among the three present study tribes of Manipur, based on three sites at the DRD2 locus.

\begin{tabular}{|c|c|c|}
\hline Population & $r_{\mathrm{ii}} \pm \mathrm{SE}$ & $H_{\mathrm{i}} \pm \mathrm{SE}$ \\
\hline Rongmei & $0.025053 \pm 008141$ & $0.455379 \pm 0.044048$ \\
\hline Inpui & $0.003405 \pm 0.001944$ & $0.474117 \pm 0.009301$ \\
Liangmai & $0.014255 \pm 0.006600$ & $0.471860 \pm 0.009400$ \\
\hline
\end{tabular}




\section{International Journal of Science and Research (IJSR) \\ ISSN (Online): 2319-7064}

Index Copernicus Value (2013): 6.14 | Impact Factor (2014): 5.611

Regression analysis: $\mathrm{H}_{\mathrm{i}}=b \quad\left(1-r_{\mathrm{ii}}\right) ; \mathrm{H}_{\mathrm{i}}$ plotted against1$r_{\text {ii }}$ through the origins has $t=-1.0280,1 \mathrm{df}, \mathrm{p}>0.05$. Regression coefficient through origin $(b)=0.4739 \pm$ 0.005906 . Average heterozygosity in pooled population $\mathrm{H}=0.474007 \pm 0.013338$.

Average hetrozygosity in the pooled did not differ significantly from the regression coefficient.

\section{Discussions}

The frequencies of ancestral allele B2 at the TaqI B site in India ranges from $36.67 \%$ in the Onge tribe (Bhaskar et al., 2008 ) to $91 \%$ in the Toda tribe (Vishwanathan et al., 2003). The average value computed for the B2 allele (0.67) in the present study is close to its corresponding value of 0.68 computed from various available studies including TibetoBurman speaking groups as well as other linguistuistic groups from tribal populations of India (Vishwanathan et al., 2003; Bhaskar et al., 2008; Prabhakaran et al., 2008; Saraswathy et al., 2009a, 2009b, 2009c) and East Asian populations but not close to the average value of $90 \%$ and $85 \%$ obtained for African and European populations respectively (Kidd et al., 1998). High A2 allele frequency in almost all the presently studied populations is of similar pattern to B2 allele distribution, and is in accordance with the available Indian populations, the East Asian and European populations (Kidd et al., 1998) where both alleles vary between $40 \%$ and $68 \%$ but is contrast to Africa. The ancestral D2 allele frequency of the present study ranges from $52 \%$ and $65 \%$ is comparable to other available Indian study but contrast to other world populations where D2 allele is found higher among African populations (60-90\%) and among Asian (90\%), and lower amongEuropean populations i.e. $38-52 \%$ (Kidd et al, 1998).

Haplotype analysis reveals that the studied populations share six of the eight haplotypes pointing toward genetic uniformity of these populations at the DRD2 locus and hints toward a common ancestry. Genetic structure analysis in the present study based on regression of heterozygosity on genetic distance also indicates that none of these three tribal groups are either very isolated or overtly admixed. The highest ancestral haplotype frequency among the Liangmai has been supported to the origin hypothesis that Liangmai $(19.2 \%)$ is the oldest among the three populations (AZSU 2009; Pamei 1949 (Edited by G. Gwangphun). The ranges of ancestral haplotype B2D2A1 (6.8-19.2\%) in the three tribal populations of Manipur is not as high as that observed for African populations (Kidd et al., 1998), but is comparable to the findings from south Indian and west Indian populations which ranges from $1.9 \%$ in Dangi Bhil (Kshatriya et al., 2010) and $16.6 \%$ in Malayali (Prabhakaran et al., 2008). This is in contrast to the findings among European population where the frequency of ancestral haplotypes ranges mostly between $0 \%$ and 4\% (Kidd et al., 1998) and Indo-European speaking North Indian populations where the ancestral haplotypes ranges from $1 \%$ and $10 \%$ (Saraswathy et al 2009a). Therefore, our findings do not rule out the possibilities suggested by Prabhakaran et al. (2008) that the ancestral haplotype could have arisen from India and then carried to other parts of the world and/or this haplotype is not specific to Africa.
Further, most recently derived haplotypes B1D1A1 and B1D1A2 are not found in any of the North Indian (Saraswathy et al., 2009c) and most of the European population (Kidd et al., 1998). But these two derived haplotypes are present in nearly all of the South Indian Dravidian speaking populations (Vishwanathan et al., 2003; Bhaskar et al., 2008; Prabhakaran et al., 2008; Saraswathy et al., 2009c) and are also present in 5 out of 11 tribes of Gujarat (Kshatriya et al., 2010). Interestingly, these two derived haplotypes are presentin all the three tribes of Manipur implying that the tribal groups of Manipur could have been part of the older population substratum of this subcontinent (Gazi et al., 2013; Krithika et al., 2013; Kshatriya et al., 2011). This is further substantiated by the observation that waves of immigrants (Tibeto-Burman groups) were considered to have arrived from the East after 6000ybp (Krithika et al., 2013), thus strengthening the antiquity of these tribal groups of north east India.

\section{Conclusion}

The present studies find out the genetic affinities and their evolutionary history among the three Naga tribal groups of Manipur. Their heterozygosity pattern does not vary much and the haplotype frequency of the three groups shared six of the eight possible haplotypes which identify the underlying genetic uniformity and their common ancestors. The findings of ancestral haplotype frequency B2D2A1also reveal that the highest ancestral haplotype frequency among the Liangmai had supported to the origin hypothesis that Liangmai (19.2\%) is the oldest among the three populations as suggested by All Zeliangrong Student Union in 2009.

\section{Acknowledgements}

The authors show a gratitude to the individuals who volunteered to provide blood samples for the present study. We are grateful to Dr. Sanju Kumar, Head of Department, Department of Biotechnology, Manipur University, for extending help in DNA extraction by providing laboratory facilities. We also wish to thank Department of Anthropology, University of Delhi, for providing us financial assistance.

\section{References}

[1] All Zeliangrong student union (AZSU) 2009.A brief account of Zeliangrong Nagas. Printed at Saraighat Offset Press Bamunimaidam, Guwahati-21.

[2] Beteille A (1998).The Indian heritage- a sociological perspective.In :Balasubramian D, Rao NA (eds) The Indian Human Heritage. University Press, Hyderabad, india, pp 87-94.

[3] Bhaskar LVKS, Thangaraj K, Mulligan CJ, et al. (2008). Allelic variation and haplotype structure of dopamine receptor gene DRD2 in nine Indian populations. Genet Test 12:153-160.

[4] Cann RL (2001). Genetic clues to dispersl of human populatons: retracing the past from the present. Science 291:742-1748. 


\section{International Journal of Science and Research (IJSR) \\ ISSN (Online): 2319-7064}

Index Copernicus Value (2013): 6.14 | Impact Factor (2014): 5.611

[5] Castiglione CM, Deinard AS, Speed WC, et al. (1995).Evolution of haplotypes at the DRD2 locus. Am J Hum University Press, Princeton, NJ.

[6] Census of India (2001).Registrar General and Census commissioner, Government of India.

[7] Cordaux R, Weiss G, Saha N, et al. (2004). The Northeast IndianPassageway: a barrier or corridor for human migrations? Mol Biol Evol 21:1525-1533.

[8] Excoffier L, Laval G, Schneider S (2005). Arlequin, version 30: anintegrated software package for population genetics dataanalysis. Evol Bioinform Online 1:47-50.

[9] Gazi NN, Tamang R, Singh VK, et al.(2013). Genetic structure of Tibeto-Burman populations of Bangladesh: evaluating the gene flow along the sides of Bay-ofBengal. PloS one, 8, e75064.

[10] Grandy DK, Litt M, Allen L, et al. (1989). The human dopamine D2 receptor gene is located on chromosome 11 at q22-q23 and identifies a TaqI RFLP. Am J Hum Genet 45:778-785.

[11] Grierson GA (1903).Linguistic Survey of India Vol III Part II (Reprint 1967). Banarasidaas, Delhi.

[12] Grierson GA (1909). Linguistic Survey of India: Tibeto-Burmanfamily Vol. III Part I. Superintendent, Government PrintingPress, Calcutta.

[13] Harpending HC, Ward R (1982).Chemical systematics and human evolution. In: Nikecki M (ed) Biochemical Aspects of Evolutionary Biology. University of Chicago Press, Chicago pp 213-256.

[14] Hauge X, Grandy D, Eubanks J, et al. (1991).Detection andcharacterization of additional DNA polymorphisms in thedopamine D2 receptor gene.Genomics 10:527530 .

[15] Karve I. (1961). Hindu society-an interpretation. Poona: Desh- mukhPrakashan.

[16] Kidd KK, Pakstis AJ, Castiglione CM, et al. (1996). DRD2 haplotypes containing the TaqI A1 allele: implications for alcoholism research. Alcohol ClinExp Res 20: 697-705.

[17] Kidd KK, Morar B, Castiglione CM,et al. (1998).A global survey of haplotype frequencies and linkage disequilibrium at the DRD2 locus.Hum Genet 103:211227.

[18] Krithikas, Maji S, Vasulu TS (2013).Molecular Biological Perspectives of Tribes in India.Journal of the Anthropological Survey of India, 62(2), 775-804.

[19] Kshatriya GK, Aggarwal A, Khurana P, et al.(2010). Genomic and linguistic affinities: a study of allelic and haplotype diversity at DRD2 locus among the tribes of Gujarat, western India. Genetic testing and molecular biomarkers, 14(2), 215-223.

[20] Kshatriya GK, Aggarwal A, Khurana P, Italia YM (2011). Genomic congruence of Indo-European speaking tribes of western India with Dravidianspeaking populations of southern India: A study of 20 autosomal DNA markers. Annals of human biology, 38(5), 583-591.

[21] Majumder PP (1998). People of India: biological diversity and affinities. EvolAnthropol 6:100-110

[22] Malhotra KC, Valusu TS (1993). Structure of human populations of India.In:Majumder PP(ed) Human Population Genetics. Plenum Press, New York, pp 207275.
[23] Miller SA, Dykes DD, Polesky HF (1988). A simple salting out procedure for extraction DNA from human nucleated cells.Nuceic Acids Res 16: 1215.

[24] NgamthuiyangnPamei 1949. Edited by G. Gwangphun, Hungmeinaga people organization.

[25] Ota T (1993). Dispan: Genetic Distance and Phylogenetic Analysis.Institute of Molecular evolutionary Genetics, PennsylvaniaStates University, University Park, PA.Parsian A, Fisher L,

[26] Parsian A, Fisher L, O'Malley KL, \& Todd RD (1991). A new Taql RFLP within intron 2 of human dopamine D2 receptor gene (DRD2). Nucleic acids research, 19(24), 6977-6977.

[27] Plagnol V, Wall JD (2006).Possible ancestral structure in humanpopulations.PLoS Genet 2:972-979.

[28] Prabhakaran K, Ramesh A ,Usha Rani MV, et al. (2008). Did human DRD2 haplotypes originate in India? A survey of haplotype frequencies and linkage disequilibrium in the tribes of Eastern Ghats, South India.CurrSci94: 1589-1594.

[29] Ratnagar S (1995).Archaeological perspectives of early Indian societies. In: Thapar R (ed) Recent Perspectives of Early IndianHistory. Popular Pakashan, Bombay, India, pp 1-52.

[30] Reddy BM, Langstieh BT, Kumar V, et al. (2007). Austro-Asiatic tribes of northeast India provide hitherto missing genetic linkbetween south and southeast Asia. PLoS2:e1141.

[31] Saraswathy KN, Meitei SY, Gupta V, et al. (2009a). Allelic and Haplotypic structure at DRD2 locus among five North Indian caste populations.Am $J$ PhysAnthropol (In press).

[32] Saraswathy KN, Meitei SY, Murry B, et al. (2009b).Population severance in Manipur at DRD2 locus.Genet Test Mol Bio-markers (In press).

[33] Saraswathy KN, Mukhopadhyay R, Shukla D, et al. (2009c).Haplotype diversity and linkage disequilibrium at DRD2 locus- a study on four population groups of Andhra Pradesh, India.Genet Test 13: $115-119$

[34] Thapar (ed) (1995).The first millennium B.C. in northern India (up to the end of Mauryan period).In : Recent Perspectives of Early Indian History. Popular Prakashan, Bombay, India, pp 80-141.

[35] The International HapMap Consortium (2005).A haplotype mapof the human genome.Nature 437:1299_ 1319.

[36] Tishkoff SA, Dietzsch E, Speed W, Pakstis AJ, et al. (1996). Global patterns of linkage disequilibrium at the CD4 locus and modern human origins. Science, 271(5254), 1380-1387.

[37] Vishwanathan H, Edwin D, Usha Rani MV, et al. (2003).A survey of haplotype frequencies and linkage disequilibrium at the DRD2 locus in the Nilgiri hill tribes, South India.CurrSci 84:566-570.

[38] Yeh F, Yang R (1999).POPGENE.Microsoft WindowBasedFreeware for Population Genetic Analysis.Version 1.31.Universityof Alberta, Edmonton, Alberta, Canada. 